\title{
NEW AND NOTEWORTHY SPECIES OF ASIATIC JASMINUM
}

\author{
Clarence E. Kobuski
}

Jasminum (§Unifoliolata) albicalyx, spec. nov.

Frutex scandens ramulis pubescentibus. Folia opposita vel subopposita, simplicia, membranacea, sparse pubescentia, saepe in axillis nervorum barbata, ovata, 6-9 $\mathrm{cm}$. longa, 3-4.2 cm. lata, basi subrotundata vel cuneata, apice acuta, subtus albida, costis venisque elevatis, petiolis 2-4 mm. longis. Inflorescentia cymosa, triflora, subsessilis, duobus paribus bractearum anguste linearium 6-8 $\mathrm{mm}$. longarum suffulta. Calyx albidus, puberulus, tubo $2 \mathrm{~mm}$. longo, lobis 5-6 subulatosetaceis 6-9 cm. longis. Corolla alba, tubo $14 \mathrm{~mm}$. longo, lobis 5, ca. 5 $\mathrm{mm}$. longis ovatis acuminatis. Fructus ignotus.

Kwangsi: Yung Hsien, Ch'ang An, over rocks in forest, alt. 200 m., A. N. Steward \& H.C. Cheo 1172, (Type AA) Oct. 23, 1933 (vine with white flowers).

This unusual species is characterized by its three-flowered cyme in which the calyces are white or yellowish white. The flowers are subsessile or nearly so, subtended by two pairs of bracts with the upper pair of bracts occasionally longer than the lower pair. The leaves are dull green in some cases and gray-green in others. The midrib and veins are elevated on the lower surface, and white or yellowish white. Scattered pubescence is found on the lower surface, often in clusters in the axils of the lower veins. The branchlets and of ten the leaves are not always truly opposite, as is usually the case in the section Unifoliolata.

Jasminum (§Unifoliolata) cinnamomifolium, spec. nov.

Frutex scandens, 1-2 m. altus, glaber, ramulis gracilibus teretibus. Folia opposita, simplicia, coriacea, oblong-lanceolata, 7-10 cm. longa, 2-3 cm. lata, basi late cuneata, raro subrotundata, apice acuminata, supra viridia, subtus paullo pallidiora, trinervia, nervis duobus lateralibus e basi ad medium rectis, supra undulatis; petioli $7-10 \mathrm{~mm}$. longi. Inflorescentia triflora in apice ramulorum, 1 vel 2 paria foliorum et basin versus 1 vel 2 paria bractearum minutarum gerentium; calyx glaber, tubo gracili, ca. $3 \mathrm{~mm}$. longo, lobis 5, subulato-setaceis ca. $2 \mathrm{~mm}$. 
longis; corolla alba, tubo ca. $1 \mathrm{~cm}$. longo, lobis 9 lineari-lanceolatis ca. $3 \mathrm{~cm}$. longis, $1.5-2 \mathrm{~mm}$. latis. Fructus in sicco flavescens (viridis ex collectore) carpidio solitario late ovoideo $10-11 \mathrm{~mm}$. longo et 9-10 $\mathrm{mm}$. lato.

Hainan: Kumyun, on slope in dense woods, S. K. Lau 27620 (TyPE AA), Aug. 6, 1936 (scandent, twining, $1 \mathrm{~m}$. high; leaves green above; fruit green). - Loktung, in dense woods, S. K. Lau 27106, June 12, 1936 (climbing, $2 \mathrm{~m}$.; leaves green above; flowers yellowish white).

Jasminum cinnamomifolium is characterized by three-nerved, coriaceous, oblong-lanceolate leaves, flowers in threes and solitary fruits. In the leaves, the two main lateral veins begin at the base and curve evenly along the margin for the basal half of the leaf. In the upper half, these same veins become somewhat undulate upon being joined by less conspicuous cross-veins. The flowers, in clusters of threes, terminate axillary branchlets. On these branchlets occur either a single or two pairs of leaves plus one or two pairs of minute bracts. In Lau 27105 (flowering specimen), these leaves are like the main stem leaves in size and shape $(7-10 \mathrm{~cm}$. long, 2-3 cm. wide). However, in Lau 27620 (fruiting specimen), these branchlet leaves, although similar in shape are considerably smaller $(2.7-3.5 \mathrm{~cm}$. long, $0.85-1.0 \mathrm{~cm}$. wide)

This species is closely related to J. urophyllum Hemsley but can be easily separated by the subulate-setaceous calyx-lobes. In J. urophyllum the calyx-lobes are very short and acute.

Another closely allied species is J. laurifolium Roxb. This species can be separated from $J$. cinnamomifolium by its narrower, heavy coriaceous leaf with revolute margin. Because of the heavier texture of the leaf, the two main lateral veins are obscured while the midrib is most outstanding. The flowers, in both species, are in threes. In $J$. laurifolium the three pedicels of the flowers are joined to a common peduncle. In the present species, there is no peduncle.

The following specimen, $C . W$. Wang 72764 , collected in Yunnan at Chen-Kang Hsien, in March 1936 at an altitude of 1400 m. undoubtedly belongs to this species. It is a rather wretched specimen consisting of two detached leaves and a single unopened flower. However, these same leaves, such as they are, and the single flower, along with the terminal floral arrangement of the specimen are enough to show that it belongs with this species. This specimen was not used in compiling the original description because of its fragmentary nature and its origin (Yunnan). Before citing Yunnan as a record of spontaneous growth, better specimens should be collected. 
Jasminum cinnamomifolium Kobuski var. axillare, var. nov.

A typo differt floribus axillaribus, calycis lobis longioribus (4-16 mm.).

Yunnan: Chen-Kang Hsien, ravine, alt. 2000 m., C. W. Wang 72170, March 1936 (vine with greenish yellow flowers). - Chen-Kang Hsien, ravine, alt. 1600 m., C. W. Wang 72261 (Type AA), March 1936 (flowers white). - Keng-Ma, woods, alt. 1600 m., C. W. Wang 72830, Apr. 1936 (vine with greenish white flowers). - Fo-Hai, mixed forest, alt. 1550 m., C. W. Wang 73847, May 1936 (vine with greenish yellow fruit). - Keng-Ma, ravine, alt. 1670 m., C. W. Wang 72892, Apr. 1936 (vine with white flowers). - Nan-Chiao, forest on mountain slope, alt. 1350 m., C. W. Wang 75013, June 1936 (vine with green fruit). - LanTsang Hsien, ravine, alt. 1600 m., C. W. Wang 76498, May 1936 (vine with green fruit).

The chief differences of this variety from the species are the axillary flowers and the elongated calyx-lobes. The lobes of the species measure approximately $2 \mathrm{~mm}$. long. In the variety calyx-lobes varied from 4-6 $\mathrm{mm}$. found in Wang 75013, 72830 and 72170 to $12-16 \mathrm{~mm}$. found in Wang 72261 and 73847 . In the species the flowers are found in threes and always terminating axillary flower branchlets. In the variety, the flowers are usually solitary and confined to the leaf axils.

Jasminum laurifolium Roxburgh, Hort. Bengal. 3. 1814, nom.; Fl. Ind. 1: 91. 1821. - DeCandolle, Prodr. 8: 303. 1844. - Kurz, For. Fl. Brit. Burma, 2: 152. 1877. - C. B. Clarke in Hooker f., Fl. Brit. Ind. 3: 597. 1882. - Kobuski in Sunyatsenia, 3:110. 1936.

Jasminum angustifolium Ker in Bot. Reg. 7: t. 521. 1821, non Willd.

Jasminum angustifolium Ker var. $\beta$ laurifolium Ker in Bot. Reg. 7: t. 521. 1821.

Kwangsi. Sha p Ma n $\mathrm{T}$ a a i S h a n : near Iu Shan village, s.e. of Shangsze, Kwangtung border, fairly common in dry, silt or sandy soil, W. T. Tsang 22194, May 3, 1933 (scattered shrubs, 1 m. with fragrant white flowers). - near Hoh Lung village, s.e. of Shang-sze, Kwangtung border, in dry steep slope of silt and solid rock, $W . T$. Tsang 22498, June 18, 1933 (fairly common shrub $1 \mathrm{~m}$. high with blueblack fruit). - Tang Lung village, s.e. of Shang-ze, Kwangtung border, in thicket, W. T. Tsang 24259, September 14, 1934 (fairly common climber $1.5 \mathrm{~m}$. high; fruit bluish black). - $\mathrm{H}$ a i n a n : Mo San Leng, in forest, alt. 900 m., N.K. Chun \& C. L. Tso 44306, Nov. 1932 (bushy shrub $1-1.5 \mathrm{~m}$. high). 
In 1936, Jasminum laurifolium Roxburgh* was reported from China, probably for the first time. Since then three more collections have come to the attention of the author, two from Kwangsi and one from Hainan. Formerly this handsome shrub was known only from India.

Kurz in For. Fl. Brit. Burma says that the fruit is above $1 / 3$ inch long. This is the only reference to fruit size that I have been able to find in literature. The Hainan specimen collected by Chun \& Tso possesses a single fruit, broadly oblong measuring $18 \mathrm{~mm}$. $\times 11 \mathrm{~mm}$. This is much larger than fruit cited by Kurz, in fact, the largest fruit I have ever seen in the genus Jasminum. Since only a single specimen is available, I have hesitated to examine it other than externally and to make measurements hoping for future specimens to make sectional examination. Also it appears from this meagre specimen that the inflorescence is one-flowered rather than three-flowered as is the typical case.

Kurz in speaking of the leaves says, "leaves linear to linear-lanceolate, rounded or acute at the base, on a 2 lin. long petiole jointed at the middle, 2-5 in. long, bristly acuminate, entire, glabrous, thinly coriaceous, the lateral nerves thin and uniting from the base into a more or less distinct intramarginal nerve and without any net-veination between them." Tsang 24259 possesses larger leaves (up to $10 \mathrm{~cm}$. long, $3.1 \mathrm{~cm}$. wide) than the other cited specimens (up to $6.0 \mathrm{~cm}$. long, $1.8 \mathrm{~cm}$. wide). Also Tsang 24259 instead of being 3-nerved is several-nerved. The two basal lateral nerves run parallel to the margin. Besides these, are usually 2 more pairs of veins also parallel beginning further up the midrib. These veins do not join with the outer veins as cross-veins. In the other cited specimens are found obscure cross-veins which occasionally join with the marginal parallel veins making the latter somewhat undulate. In some leaves the veining is similar to Tsang 24259 and in other cases as obscure as those mentioned by Kurz.

Jasminum (§Unifoliolata) pericallianthum, spec. nov.

Frutex scandens glaber. Folia opposita, simplicia, coriacea, oblongoovata, 11-17 cm. longa, 4-6.5 cm. lata, basi cuneata vel subrotundata, apice acuminata, costis venisque subtus elevatis, petiolis $8.0-8.5 \mathrm{~mm}$. longis. Inflorescentia axillaris, laxe cymosa, 6-12-flora; calyx glaber, tubo $2.5-3 \mathrm{~mm}$. longo in pedunculum incrassatum $8-8.5 \mathrm{~mm}$. longum attenuato, lobis 5 brevibus acutis ca. $0.5 \mathrm{~mm}$. longis. Corolla nivea (5 cm. diametro ex collectore), tubo gracili $3.5-4 \mathrm{~cm}$. longo, apice ampliore, lobis 5 ovatis ca. $2 \mathrm{~cm}$. longis $1.0-1.4 \mathrm{~cm}$. latis. Fructus ignotus.

*Kobuski in Sunyatsenia, 3: 110. 1936. 
Burma: hills east of Fort Hertz, alt. 1200 m., F. Kingdon Ward 9078, Dec. 30, 1930 (magnificent twining climber in the jungle; flowers snow white, fragrant, 2 inches across, tube $13 / 4$ inches).

"A magnificent twining climber in the jungle." In his field-notes, F. Kingdon Ward makes this memorandum. On looking at the specimen, one can readily see why he so describes it. With flowers, equalled by no Jasminum ever studied by the author, this species is probably one of the most beautiful in the genus. Loose cymes of snow-white fragrant flowers which easily measure two inches across the corollalobes, and corolla tubes nearly two inches in length are outstanding characters of the species. Also the stocky thickened pedicels which enlarge starting from the base until nearly of the same size as the calyx-tube with scarcely any constriction at this point offer another interesting specific distinction.

Jasminum (§Unifoliolata) pilosicalyx, spec. nov.

Frutex scandens ramulis dense pilosis. Folia opposita, simplicia, papyracea, ovato-elliptica, $8.5-11 \mathrm{~cm}$. longa, 5-7.5 cm. lata, basi subcordata vel subrotundata, apice obtusa subito acuminata, margine ciliata, costa venisque subtus pilosis, petiolis 7-9 mm. longis. Inflorescentia axillaris, cymosa triflora. Flores immaturi. Calyx dense pilosus, tubo 1-1.5 mm. longo, lobis 5 subulato-setaceis 5-6 mm. longis. Fructus ignotus.

Hainan: Po-ting, in forest, alt. 400 m., F. C. How 73094, July 5. 1935 (bark gray; leaves green above, pale green beneath; calyx with white pubescence).

A pubescent calyx in the genus Jasminum is no novelty. However, the white pilose pubescence of $J$. pilosicalyx is the most distinctive calyx pubescence seen in any species of the genus. This white pilosity may exist only in the early flowering stage since the stems and leaves are also pilose but of a more nearly tan color. Since only a single immature flower can be found on How's specimen, it is difficult to obtain any true concept of the corolla's ultimate proportion. The papyraceous, ciliate leaves are other distinctive features of the species.

Jasminum (§Unifoliolata) Rehderianum Kobuski in Sunyatsenia, 3: 110. 1936 .

This outstanding species is confined so far as known at present to Hainan. It has been collected four times from this region, twice by H. Y. Liang $(62844,62986)$ in September 1933, once by C. Wang (33768) in August 1933 and finally by C. I. Lei (1456) in August 1934. 
Lei remarks that it is found abundantly in the Lam ko district and vicinity on dry gentle slopes, in sand and on rocky seashore.

Jasminum (§Unifoliolata) robustifolium, spec. nov.

Frutex scandens robustus glaber. Folia opposita, simplicia, coriacea, oblongo-ovata, basi cuneata vel subrotundata, apice acuminata, 10-22 $\mathrm{cm}$. longa, 5-9.3 cm. lata, venis lateralibus ad costam perpendicularibus, petiolis robustis $2-2.5 \mathrm{~cm}$. longis, ad $2 \mathrm{~mm}$. latis. Inflorescentia paniculata, axillaris. Flores ignoti. Fructus cinnabarinus (ex collectore) unicus visus carpidio uno tantum ovato $13-15 \mathrm{~mm}$. longo 7-10 mm. lato.

Yunnan: Tsang-Yuan, ravine, alt. 1200 m., C. W. Wang 73304, Apr. 1936 (vine with orange-red fruit) (AA).

Closely allied to $J$. Wangii, but separated easily by its paniculate inflorescence and leaves with nearly perpendicular rather than acutely angled veining. This species is very outstanding in the genus because of its very large leaves and generally robust stature. In China, its nearest ally in size is J. coffeianum Hand.-Mazz. However, again its paniculate inflorescence separates the two. Also, the leaves in $J$. coffeianum are more coriaceous.

Jasminum (§Unifoliolata) Wangii, spec. nov.

Frutex scandens glaber, ramulis minutissime glandulosis. Folia opposita, simplicia, coriacea, oblongo-ovata, 15-26 cm. longa, 6.8-10.3 $\mathrm{cm}$. lata, decidua, basi cuneata vel subrotundata, apice subito acuminata, venis subangulo acuto divergentibus, petiolis ca. $2 \mathrm{~cm}$. longis. Inflorescentia racemosa, terminalis axillarisque, pedicellis pedunculisque glandulis minutissimis dense dispositis. Calyx glaber, pedicello 1.5-2.5 $\mathrm{cm}$. longo, tubo ca. $3 \mathrm{~mm}$. longo, lobis 5 acutis parvis ca. $5 \mathrm{~mm}$. longis; corolla alba, tubo gracili $2-2.5 \mathrm{~cm}$. longo, lobis $6-7$ lineari-lanceolatis vel ovatis, $10-11 \mathrm{~mm}$. longis, plerumque 2-2.5 mm. latis. Fructus ignotus.

Yunnan: Sheou-bang-chou-chian, Che-li Hsien, woods in mountainous ravine, alt. 900 m., C. W. Wang 79673 (Type AA), Sept. 1936 (leaves light green underneath; flowers white). - Kuen-ger, Che-li Hsien, in mixed forest, alt. 1000 m., C. W. Wang 79217, Oct. 1936 (vine $2 \mathrm{~m}$. long; flowers white). - Jah-leei, Che-li Hsien, in mixed forest, alt. $1400 \mathrm{~m}$., C. W. Wang 79151, Oct. 1936 (climber in forest with white flowers).

Jasminum Wangii closely resembles J. robustifolium from which it is easily separated by the racemose inflorescence, veins at an acute angle and by the dense covering of minute glands on the young branches 
and pedicels of the inflorescence which can be seen only under a highpowered binocular. On the very young growth, especially in the inflorescence, these glands are colored orange-brown, fading either by drying or by maturity to brown. On the most mature portions of the specimen these glands fade out entirely. Compared with the usual subulate-setaceous or foliaceous calyx-lobes, generally found in the genus, the lobes of this species seem quite reduced. The corolla lobes of Wang 79151 differ from the other two specimens cited in being ovate ( $5 \mathrm{~mm}$. wide) rather than linear-lanceolate $(2-2.5 \mathrm{~mm}$. wide). In this specimen, however, there are only two flowers and of these only one had opened.

Jasminum (§Trifoliolata) anisophyllum, spec. nov.

Frutex (probabiliter scandens) $3 \mathrm{~m}$. altus, fere undique dense pilosus, ramulis floriferis teretibus. Folia opposita, membranacea, trifoliata, foliolis valde inaequalibus, terminali oblongo-ovato, basi subcordato vel rotundato, apice acuminato, $8.5-10.5 \mathrm{~cm}$. longo, $4-4.8 \mathrm{~cm}$. lato, venis primariis lateralibus $4-5$, costa supra impressa subtus elevata, petiolulo 2.5-3 mm. longo, lateralibus multo minoribus ovatis, ca. $1.4 \mathrm{~cm}$. longis, $7 \mathrm{~mm}$. latis, sessilibus vel subsessilibus; petiolis $2-3 \mathrm{~mm}$. longis. Inflorescentia axillaris cymosa. Calyx dense pilosus, tubo $3-4 \mathrm{~mm}$. longo, lobis 5 subulato-setaceis ca. $2 \mathrm{~mm}$. longis. Corolla alba, tubo gracili ca. $2 \mathrm{~cm}$. longo, lobis (5 ?) linearibus, $5-8 \mathrm{~mm}$. longis, ca. $2 \mathrm{~mm}$. latis. Fructus ignotus.

Yunnan: You-louh shan, Che-li Hsien, mixed forest, alt. $1150 \mathrm{~m}$., C. W. Wang 78119, Sept. 1936 (height 3 m.; flowers white).

Jasminum anisophyllum, J. sinense and J. Forrestianum are closely joined in a small distinctive group. The main distinction of this group is based on the lateral leaflets being markedly smaller than the terminal leaflet. In J. anisophyllum these lateral leaflets are minute in comparison with those of the other two mentioned species. In fact, the contrast between the terminal and lateral leaflets is so great that the laterals at first glance are generally mistaken for bracts. Also the lateral leaflets are sessile or subsessile in $J$. anisophyllum and the petiolule of the terminal leaflet measures only $2-3 \mathrm{~mm}$. Both these measurements are far lower than those of the other two species. The corolla-tube in $J$. anisophyllum measures approximately only $2 \mathrm{~cm}$. long. Corolla-tubes of $J$. sinense can be found measuring up to $4 \mathrm{~cm}$. The pilose pubescence is another outstanding feature of $J$. anisophyllum. This pubescence exists over the whole plant and is most pronounced on the midrib and veins of the leaves and on the calyx. 
Jasminum (§Trifoliolata) Forrestianum, spec. nov.

Frutex scandens glaber, 2.5-6 m. altus ramulis floriferis angularibus vel sulcatis. Folia opposita, trifoliata vel simplicia, coriacea vel subcoriacea, foliolis inaequalibus, terminali oblongo-ovato, basi truncato vel subcordato, apice acuminato, $6-13 \mathrm{~cm}$. longo, $3.3-6.2 \mathrm{~cm}$. lato, costa supra impressa, subtus elevata, petiolulo $1.2-2 \mathrm{~cm}$. longo, lateralibus minoribus ovatis, basi obliquis, apice acuminatis, ca. $3.5-6 \mathrm{~cm}$. longis, $1.9-3 \mathrm{~cm}$. latis, petiolulis $1.5-2 \mathrm{~mm}$. longis, petiolis $1.3-2 \mathrm{~cm}$. longis. Inflorescentia cymosa vel subpaniculata, axillaris. Pedicelli 5-6 mm. longi. Calyx glaber, tubo $1.5-2 \mathrm{~mm}$. longo, lobis 5 minutissimis triangularibus vix $0.5 \mathrm{~mm}$. longis. Corolla extus rosea vel pallide purpurea, intus cereo-alba, tubo $1.2-1.5 \mathrm{~cm}$. longa, lobis 5 ovatis $7-9 \mathrm{~mm}$. longis ca. $6 \mathrm{~mm}$. latis. Fructus (atrovirens, ex collectore) in sicco flavescens, carpellis duobus vel solitariis, late globosis, ovoideis vel subrotundatis, ca. $10 \mathrm{~mm}$. longis.

Yunnan: Flanks of the Mingkwong Valley, on trees and shrubs, lat. $25^{\circ} 15^{\prime}$ N., alt. 2135 m., G. Forrest 7861 (Type AA), May 1912 (scandent shrub 2.5-6 m.; flowers interior waxy white, exterior flushed crimson-rose, deliciously fragrant). - Precise locality and date lacking, G. Forrest 9811. - Chen-Kang Hsien, alt. 2800 m., C. W. Wang 72464, March 1936 (climbing; flowers light purple). - Chen-Kang Hsien, alt. 2600 m., C. W. Wang 72462, March 1936 (fruit green). - Lung-ling Hsien, along stream, alt. 2200 m., H. T. Tsai 55006, Jan. 7, 1934 (climbing shrub with green to black fruit). - Lung-ling Hsien, in forest, alt. 1800 m., H. T. Tsai 55745, Apr. 11, 1934 (climbing shrub with dark purple fruit). - Shang-pa Hsien, in ravine, alt. 2000 m., H. T. Tsai 54520 (twining shrub). - Locality and date lacking, H. T. Tsai 57012 .

Jasminum sinense is the closest relative of this species and may be easily separated by its long graceful corolla-tubes (up to $4 \mathrm{~cm}$.), slender corolla-lobes and subulate-setaceous calyx-lobes. In J. Forrestianum the corolla-tubes are less graceful and measure only up to $1.3 \mathrm{~cm}$.; the corolla-lobes are much broader and the calyx-lobes are small. Also the stamens are clearly exserted while in J. sinense, the stamens are inserted.

From J. anisophyllum, another close relative, it can be separated by its glabrous, long-petioled leaves, longer petiolulate lateral leaflets, small calyx-lobes and furrowed flowering branches.

This species naturally falls in the section Trifoliolata because of its usually trifoliolate leaves. Occasionally, specimens are found which 
are unifoliolate (Forrest 9811, Tsai 54520, 55745). However, Tsai 54520 , for example, even though mostly simply leaved, has occasional trifoliolate leaves. Since the specimens cited above agree in all other features, it seems undesirable to separate them on this variable character.

The veins are distinctly impressed on the upper surface and elevated on the lower surface. Also the lateral veins sweep upward near the margin and join with the veins immediately above, thus making an undulating marginal vein.

Jasminum Forrestianum is named after that indefatigable botanical collector, the late George Forrest, to whom we owe so much of our knowledge of the extremely rich flora of western China and the adjoining regions.

Arnold Arboretum, HARVARD UniVERSITY. 


\section{$2 \mathrm{BHL}$ Biodiversity Heritage Library}

Kobuski, Clarence E. 1939. "New and Noteworthy Species of Asiatic Jasminum." Journal of the Arnold Arboretum 20(1), 64-72. https://doi.org/10.5962/p.185395.

View This Item Online: https://www.biodiversitylibrary.org/item/33596

DOI: https://doi.org/10.5962/p.185395

Permalink: https://www.biodiversitylibrary.org/partpdf/185395

\section{Holding Institution}

Missouri Botanical Garden, Peter H. Raven Library

\section{Sponsored by}

Missouri Botanical Garden

\section{Copyright \& Reuse}

Copyright Status: In copyright. Digitized with the permission of the rights holder.

Rights Holder: Arnold Arboretum of Harvard University

License: http://creativecommons.org/licenses/by-nc-sa/3.0/

Rights: https://biodiversitylibrary.org/permissions

This document was created from content at the Biodiversity Heritage Library, the world's largest open access digital library for biodiversity literature and archives. Visit BHL at https://www.biodiversitylibrary.org. 